\title{
FATIGUE DESIGN AND PREVENTION IN MOVABLE SCAFFOLDING SYSTEMS
}

\author{
Hugo COELHO ${ }^{1}$, Alberto TORRES, Pedro PACHECO, Cristiano MOREIRA, \\ Rute SILVA, José M. SOARES, Dânia PINTO \\ BERD, Portugal \\ Faculty of Engineering of University of Porto, Portugal
}

\begin{abstract}
The Movable Scaffolding System (MSS) is a heavy construction equipment used for casting situ of concrete bridge decks. In the past decades, MSSs have become increasingly complex and industrialized, enlarging its span ranges, incorporating auxiliary elevation machinery and increasing productivity. The tendency nowadays is for strong reutilization and the notion of MSS as a disposable or temporary structure is somehow reductive. The main structure of MSSs may be potentially exposed to fatigue, usually characterized by low number of cycles with significant stress amplitude. Fatigue may be prevented through adequate design; judicious selection of materials; demanding quality control and implementation of robust inspection and maintenance plans.
\end{abstract}

Keywords: Bridge Construction, MSS, Fatigue

\section{INTRODUCTION}

The Movable Scaffolding System (MSS) is a bridge construction equipment that combines steel structure with heavy hydraulic equipment, used for erection of concrete bridge decks.

The MSS supports the bridge deck during the concrete casting process. The concrete casting may occur in more than one stage (usually, the bottom slab and the webs are casted in the first stage and the top slab is casted in a second stage).

${ }^{1}$ Corresponding author: University of Porto, Faculty of Engineering of University of Porto, Structural Engineer, BERD, Edifício Olympus I, Av. D. Afonso Henriques, $1462-2^{\circ}, 4450-013$ Matosinhos, Portugal, tel:+351 2293995 20, www.berd.eu 
The practical case presented herein - M1-90-S - is an MSS currently in operation near Ankara, in Turkey.

The main supporting structure is a steel truss girder (Main Girder characterized by having a superior arch (bow-string type), as presented in Figure 1 and 2.

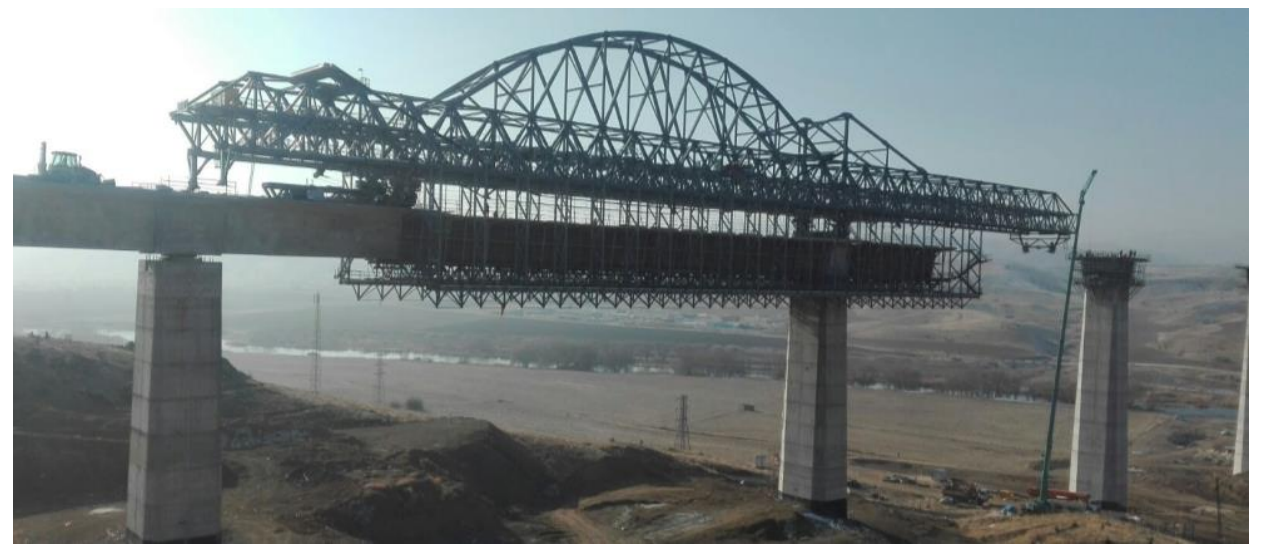

Fig. 1. Overhead MSS - M1-90-S Operating in Kirikkale, near Ankara, Turkey

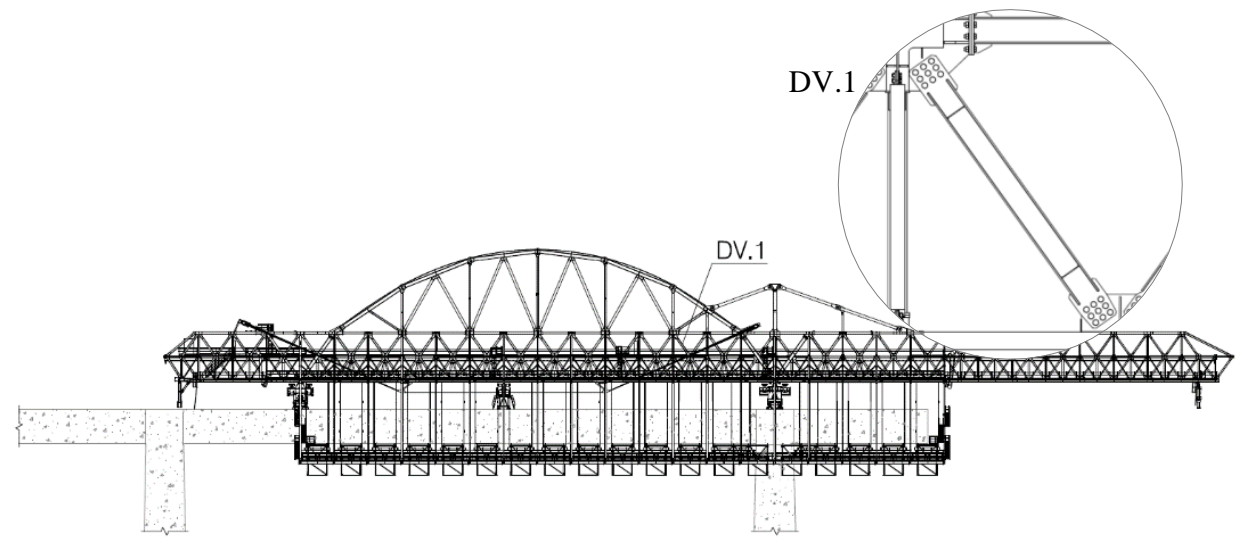

Fig. 2. Overhead MSS - M1-90-S Elevation scheme with identification of Main Girder Diagonal DV.1

During concreting stage, the Main Girder rests on top of two frames: the Pier Frame and the Rear Concreting Frame.

The Main Girder supports the Transversal Structures that embrace the deck to support the formwork, as presented in Figure 3. The formwork is suspended from the superior part of the Transversal Structures by threaded suspension bars, crossing the bridge deck section. 
After prestress is applied to the deck, the whole machine is lowered and thus unloaded from deck weight. Before launching, the suspension bars are disassembled and the formwork is separated in halves that slide apart to pass the piers. The MSS is then self-propelled to the next span.

The supporting frames are moved before and during MSS launching operation.

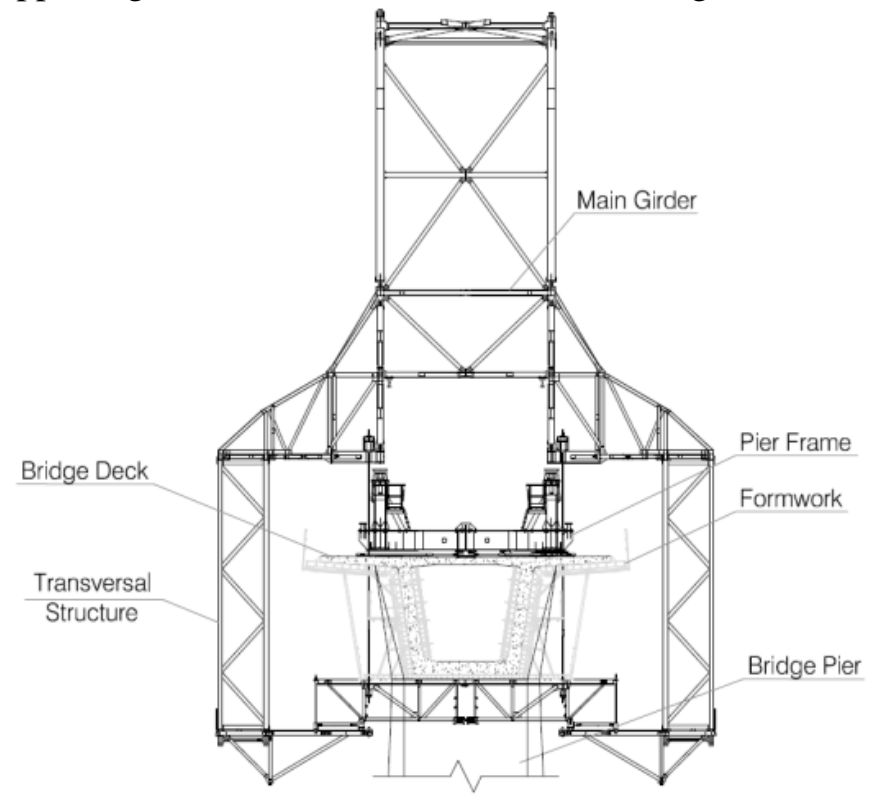

Fig. 3. Overhead MSS - Transversal scheme with identification of Main Components.

MSSs are often faced as temporary structures. Nevertheless, there are several known examples of MSS equipment that have been in service for more than two decades and that endured successive applications in different environmental conditions, submitted to several assembly and disassembly processes that are often aggressive to structural components. In some cases, the MSS has already operated in different continents, meaning that they went through open sea transportation in severe corrosion environments.

Apart from that, the ongoing tendency for productivity demand in bridge construction results in increasingly complex and industrialized MSS equipments, in many cases incorporating heavy auxiliary machines such as tower cranes or overhead cranes (Fig. 4) (Pacheco, 2015)

Given this, the temporary nature of the MSS structures per se should not be a reason for decreasing the design safety factors and the steel fabrication requirements. 


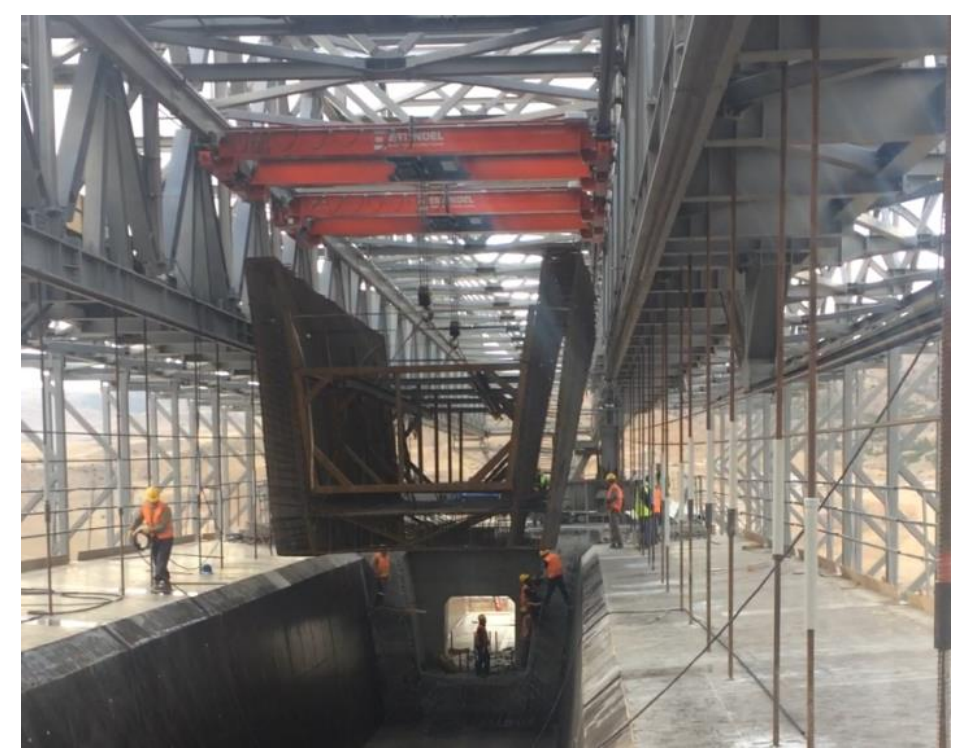

Fig. 4. M-90-S equipped with auxiliary tower cranes

\section{MSS FATIGUE EVALUATION}

\subsection{Potential causes of fatigue}

Although fatigue assessment is usually neglected in MSS Design, the main structure of a MSS may be potentially exposed to the following fatigue causes:

- Loading and unloading of the structure followed by launching, causing a significant stress amplitude;

- Action of auxiliary crane machinery such as hoists or overhead cranes (usually, affect auxiliary structures, such as rails);

- Wind effects;

- Contact fatigue in locomotion's rails surface caused by local stresses transmitted by wheels or rollers. This is a particular phenomenon and will not be discussed herein.

\subsection{An integrated approach for fatigue evaluation in MSS structures}

Since there is no specific standard for MSS Design, Annex A of EN 1993-1-9 should be used for fatigue safety evaluation. According to EN 1993-1-9, fatigue assessment should be undertaken using either Damage Tolerant Method or Safe Line Method (Sedlacek et al., 2008). 
The authors recommend the use of damage tolerant approach for MSS Design, since periodic inspection and maintenance may be easily and efficiently implemented:

- The MSS is delivered with a specific maintenance manual (CNC, 2007);

- Inspections are easy to perform during operation since the MSS is equipped with platforms and stairways and main structural components remain visible and accessible;

- The structure is periodically assembled and disassembled, allowing a strong maintenance and repair actions;

- Bolts are usually entirely replaced from application to application;

- Damaged components are frequently replaced;

- The fatigue loading history is known.

More specifically, in this real case application, the MSS structure is equipped with a monitoring system that allows a frequent assessment of structural response.

The following principles are proposed for application of Damage Tolerant Method to MSS structures:

Table 1. Principles for application of Damage Tolerant Method

\begin{tabular}{|l|l|}
\hline Variable & Description \\
\hline $\begin{array}{l}\text { Cumulative Damage } \\
\text { (between inspections) }\end{array}$ & $\begin{array}{l}\text { Dd } \leq 0.25 \text { in order to avoid significant } \\
\text { crack initiation between inspections }\end{array}$ \\
\hline $\begin{array}{l}\text { Safe service period } \\
\text { (between main inspections) }\end{array}$ & $\begin{array}{l}5 \text { years or corresponding to } 100 \text { working } \\
\text { cycles (whichever happens first) }\end{array}$ \\
\hline$\gamma_{\mathrm{Mf}}$ & 1.15 \\
\hline$\gamma_{\mathrm{Ff}}$ & 1.00 \\
\hline
\end{tabular}

\section{CTICAL CASE}

The DV.1 connection (indicated in Fig.2) is used in approximately 500 connections of the M1-90-S Main Girder diagonals, being designed to be slipresistant in service - numerical models indicate that the slipping of connection plates may increase the deflection in about $20 \%$.

The following principles were considered for fatigue assessment:

- Given the absence of an absolutely equivalent detail, the most conservative $S$ $\mathrm{N}$ curve given in EN 1993-1-9 was used $\left(\Delta s_{C}=36\right)$;

- The modified nominal stress was used. The stress concentration factor, $k_{f}$, was evaluated through FEM analysis; 
- For simplification, the Damage, Dd, was evaluated adding the Damage due to the operation cycle loading $\left(D_{d, O P}\right)$ with the Damage due to wind loading $\left(D_{d, W}\right)$ :

$$
D_{d}=D_{d, O P}+D_{d, W}
$$

\subsection{Damage due to Operation Cycle Loading}

In each Working Cycle, the MSS Main Structure is loaded (concrete casting), unloaded (MSS descending and formwork removal) and then launched.

For a member type, such as Main Girder Diagonal bar (DV.1 in Fig. 2), this loading sequence causes the equivalent to 2 or 3 "fatigue" cycles per Operation Cycle. The nominal stress history and the cycle counting in accordance with the reservoir method are given in Figure 5.

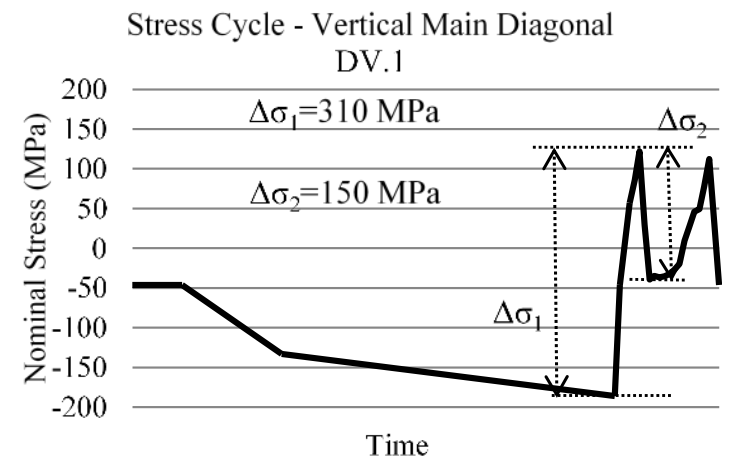

Fig. 5. Stress history and cycle counting for DV.1 (for one operation cycle)

A value of 1.4 was considered for $k_{f}$ in accordance with FEM evaluation.

The stress maps used for evaluation of the stress concentration factor are shown in Figure 6 (for ULS combination).
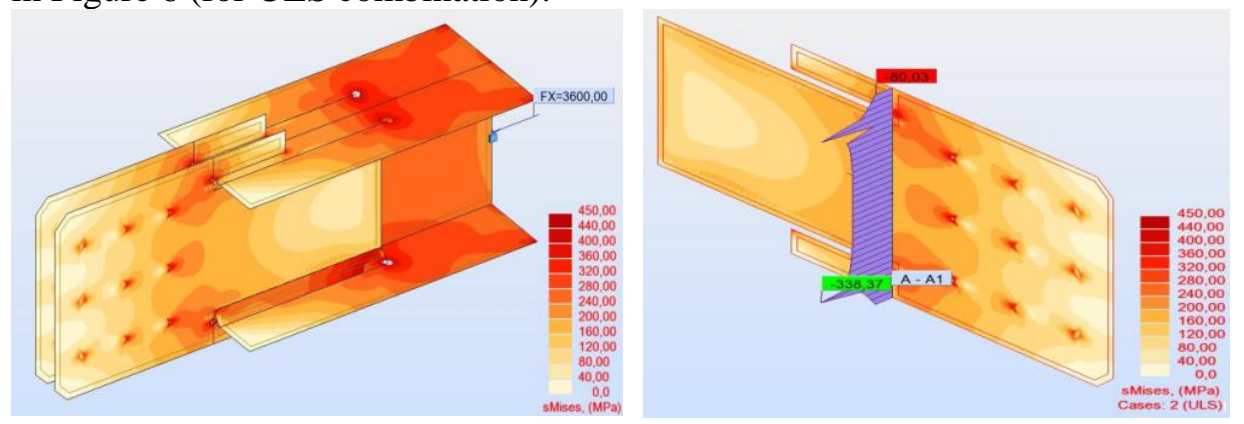

Fig. 6. FEM Model used for evaluation of $k_{f}$ Factor for DV.1 connection (left) and Normal Stress Map in DV.1 connection plates (right) - Von Mises stresses (ULS) 
The damage due to the operation cycle loading is evaluated applying Annex A of EN 1993-1-9 as follows:

$$
D_{d}=\sum_{i}^{n} \frac{n_{E i}}{N_{R i}}
$$

where $n_{E i}$ is the number of cycles associated with the stress range $\gamma_{F f} . \Delta \sigma i$ for band $i$ in the factored spectrum and $N_{R \mathrm{i}}$ is the endurance obtained from the S-N curve - or Expression (3.3) - for a stress range of $\gamma_{F f} . \Delta \sigma i$.

$$
N_{R}=\frac{\left(\Delta \sigma_{C}\right)^{m} \cdot 2 \times 10^{6}}{\left(\Delta \sigma_{R}\right)^{m}}
$$

The notations used in the previous expressions are the same used in EN 1993-1-9.

Focusing on the practical case, the damage due to operation cycle loading is evaluated as follows:

$$
\begin{gathered}
D_{d, O P}=\sum_{i=1}^{2} \frac{n_{E i}}{N_{R i}} \\
\frac{n_{E 1}}{N_{R 1}}=100 /\left[\frac{(36 / 1.15)^{3}}{(310 \times 1.4)^{3}} 2 \times 10^{6}\right] \\
\frac{n_{E 2}}{N_{R 2}}=100 /\left[\frac{(36 / 1.15)^{3}}{(150 \times 1.4)^{3}} 2 \times 10^{6}\right] \\
D_{d, O P}=0.148
\end{gathered}
$$

In the former expressions, a total of 100 operation cycles is considered (number of cycles between main inspections).

\subsection{Damage due to Wind Loading}

The standard EN 1993-3-1 gives some guidance for evaluation of fatigue caused by wind in towers and masts. Given the lack of applicable standards, a conservative methodology, with some resemblances with the later was adopted. The principles are defined next:

- Consideration of 3 years of exposition to wind in each safe period of 5 years;

- Consideration of a frequency of $0.2 \mathrm{~Hz}$ for wind action (period of $5 \mathrm{~s}$ ); 
- Total number of cycles NT = 3years / 5seconds (approximately $1.9310^{7}$ );

- Drawn up of annual wind speed distribution based on Gaussian distribution, using observed maximum daily wind speeds;

- Calculation of stress amplitude $\Delta \sigma_{W i}$ corresponding to each wind speed level Wi;

- Calculation of number of cycles $n_{i}$ corresponding to each wind speed level Wi;

- Application of Damage function discarding the lower speeds (below the cutoff limit)

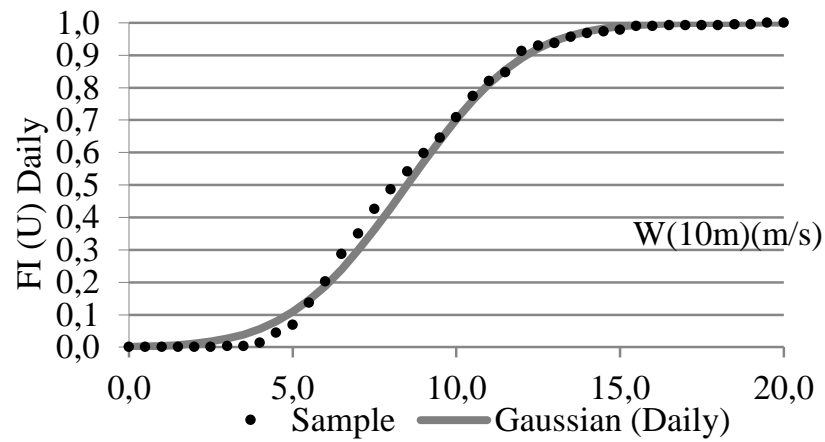

Fig. 7. Cumulative Gaussian distribution function for Ankara daily maximum wind speed (10m height from the ground level)

The Gaussian distribution and the source data used for estimation of the daily maximum wind speed are shown in Figure 7 (Firat, 2007 and Resende \& Coelho, 2015).

The values shown in Figure 7 were registered at a height of $10 \mathrm{~m}$ above flat open country terrain. The calculation of the wind speed at a height of $75 \mathrm{~m}$ (MSS operation height) may be performed by application of EN 1993-1-4 procedures. This conservative approach is summarized in Table 2, resulting in a cumulative damage of 0.0467 , for the present detail, caused by the wind fatigue loading.

Table 2. Cumulative damage calculation due to wind fatigue loading (DV.1 detail).

\begin{tabular}{|l|l|l|l|l|l|l|}
\hline $\begin{array}{l}\mathrm{W} \\
(10 \mathrm{~m}) \\
\mathrm{m} / \mathrm{s}\end{array}$ & $\begin{array}{l}\mathrm{Wi} \\
(75 \mathrm{~m}) \\
\mathrm{km} / \mathrm{h}\end{array}$ & $\begin{array}{l}\Delta \mathrm{si} \\
\mathrm{MPa} \%\end{array}$ & $\rho(\mathrm{Wi})$ & $\begin{array}{l}\mathrm{nWi}= \\
\text { NT. } \rho(\mathrm{Wi})\end{array}$ & NR,wi & $\begin{array}{l}\text { nWi/ } \\
\text { NR,wi }\end{array}$ \\
\hline 36,00 & 164,27 & 66,10 & 0,00 & 0 & 212225 & 0,00 \\
\hline 34,00 & 155,14 & 59,00 & 0,00 & 0 & 299046 & 0,00 \\
\hline 32,00 & 146,02 & 52,50 & 0,00 & 0 & 430242 & 0,00 \\
\hline 30,00 & 136,89 & 45,90 & 0,00 & 0 & 633701 & 0,00 \\
\hline 28,00 & 127.76 & 40,00 & 0,00 & 0 & 958659 & 0,00 \\
\hline 26,00 & 118,64 & 34,50 & 0,00 & 0 & 1495451 & 0,00 \\
\hline 24,00 & 109,51 & 29,40 & 0,00 & 18 & 2417379 & 0,00 \\
\hline
\end{tabular}




\begin{tabular}{|l|l|l|l|l|l|l|}
\hline 22,00 & 100,39 & 24,70 & 0,00 & 450 & 4074517 & 0,00 \\
\hline 20,00 & 91,26 & 20,40 & 0,00 & 7103 & 7218255 & 0,00 \\
\hline 18,00 & 82,13 & 16,50 & 0,00 & 69229 & 13582420 & 0,01 \\
\hline 16,00 & 73,01 & 13,10 & 0,02 & 416955 & 27535457 & 0,02 \\
\hline 14,00 & 63,88 & 10,00 & 0,08 & 1554123 & 61354155 & 0,03 \\
\hline 12,00 & 54,76 & 7,30 & 0,19 & 3589001 & & \\
\hline 10,00 & 45,63 & 5,10 & 0,27 & 5139001 & & \\
\hline 8,00 & 35,50 & 3,30 & 0,24 & 4564782 & & \\
\hline 6,00 & 27,38 & 1,80 & 0,13 & 2514675 & & \\
\hline 4,00 & 18,25 & 0,80 & 0,05 & 858682 & & \\
\hline 2,00 & 9,13 & 0,20 & 0,01 & 181570 & & \\
\hline 0,00 & 0.00 & 0,00 & 0,00 & 25760 & & \\
\hline
\end{tabular}

Grey Zone: Cut Off Limit

$\mathrm{D}_{\mathrm{d}, \mathrm{w}}=\operatorname{sum}(\mathrm{nWi} / \mathrm{NR} \cdot \mathrm{wi})=0,0467$

The joined effect of the damage due to operation cycle $\left(D_{d, O P}\right)$ and wind loading $\left(D_{d, W}\right)$ is given by:

$$
D_{d}=0.148+0.0467=0.195<0.25
$$

The result shows that the structure will most likely remain free from significant crack initiation for a period of 5 years or 100 working cycles, by which time the first main inspection must occur.

\section{FATIGUE PREVENTION DURING MANUFACTURING AND OPERATION}

The fatigue prevention is not just a question of design and must be complemented by adequate fabrication control and maintenance procedures.

As a first approach, the following measures are recommended for MSS structures fabrication:

- Main structural components should be manufactured in accordance with EN 1090-2 EXC3 execution class requirements. Regarding weld examination, the following acceptance levels are recommended: Level B in accordance with ISO 5817 and Level 2 in accordance with ISO 11666;

- All materials should be delivered with inspection certificates 3.1 or 3.2 according to EN 10204;

- All materials should be delivered with Charpy-V notch tests so that the applicability of Table 2.1 of EN 1993-1-10 may be accessed;

- The materials should be specified with adequate trough-thickness properties and specific measures must be implemented to avoid lamellar tearing during welding; 
- The welding starts and stops are often prone to imperfections - the use of adequate run-on and run-off plates is recommended;

- All welds must be accessible for inspection, not only in service but also throughout manufacturing. In some cases, it is not possible to perform ultrasonic testing, UT, or radiographic testing, RT. In such situations, the change of details or application of alternative non-destructive testing, NDT, should be considered.;

- All welds that remain hidden after fabrication should be submitted to photographic registry, complementing the NDT report;

- The NDT must be performed in the welds extension more prone to crack growth. This should be expressed in the execution drawings or fabrication specifications;

- The joint preparation should be validated before welding. The poor access for welding or the need for demanding welding positions often result in defective welds.

Complementarily, during service life of MSS structures, the following measures are recommended:

- Elaboration of a Maintenance plan which must include an inspection plan, clearly identifying the critical details, the extension of inspection and its periodicity;

- Performance of operational Maintenance, carried out periodically during MSS operation;

- Performance of deep maintenance, carried out after MSS disassembly and before each new application. Structural components with evidence of crack initiation must be retrofitted or replaced between consecutive applications;

- Detailed registry of all MSS applications, enabling the reproduction of the structure loading history and cycle counting;

- Structural monitoring is highly recommendable. Any abnormal structural behavior should trigger a consistent diagnosis. Some recent MSS equipment also incorporate active control systems, which may have a significant impact in limiting the stress range (Pacheco, 2007);

- The choice for non-slip bolted connections is recommended. Besides improving fatigue performance of bolts and connection plates, non-slip connections enable a better control of force redistribution and stress reversal (Harridge, 2011);

- All bolts should be replaced between two consecutive applications. This should be mandatory for HSFG bolts. 


\section{CONCLUSIONS}

MSS structures are often seen as temporary structures. Given the on growing longevity and complexity of this type of equipment, its temporary nature must be considered with reserve while establishing the design and fabrication criteria. One of the design issues that must be carefully considered is the fatigue assessment of MSS structures, which is often neglected. The Damage Tolerant Method seems to be an adequate approach for fatigue evaluation in MSS structures, given its specific nature.

Nevertheless, the fatigue design must be necessarily complemented by adequate fabrication control and by application of a consistent maintenance plan.

\section{REFERENCES}

1. Firat, F. K..: Development of Load and Resistance Factors for Reinforced Concrete Structures in Turkey. Ph.D Thesis, Ankara, Middle East Technical University Ankara 2007.

2. Harridge, S.: Launching Gantries for Building Pre-cast Segmental Balanced Cantilever Bridges, Structural Engi-neering International Journal of IABSE, 21, 4(2011) 406-412.

3. Manual de Cimbras Autolanzables, $1^{\text {a }}$ ed., CNC, Madrid, 2007.

4. Pacheco, P., A Scaffolding System strengthened with Organic Prestressin, in: Structural Engineering International Journal of IABSE, 17, 4 (2007) 314-321.

5. Pacheco, P.: High Productivity in Bridge Construction - the OPS effect, in: Multi-Span Large Bridges conference 2015, 243-244.

6. Resende, A., Coelho, $\mathrm{H},:$ Preliminary assessment of wind actions in large span MSS, in: Multi-Span Large Bridges conference 2015, 267-268.

7. Sedlacek, G., Feldmann, M., Kühn, B., Tschickardt, D., Höhler, S., Müller, C., Hensen, W., Stranghöner, N., Dahl, W., Langenberg, P., Münstermann, S., Brozetti, J., Raoul, J., Pope, R., Bijlaard F.: Commentary and worked examples to EN 1993-1-10 "Material toughness and through thickness properties" and other toughness oriented rules in EN 1993, JRC Scientific and Technical Report 2008. 


\title{
PROJEKTOWANIE RUCHOMYCH SYSTEMÓW RUSZTOWAŃ Z UWZGLĘDNIENIEM OBCIĄŻĘŃ ZMĘCZENIOWYCH
}

\begin{abstract}
Streszczenie
System ruchomych rusztowań - Movable Scaffolding System (MSS) to ciężki konstrukcja budowlana wspomagająca wykonanie betonowych mostów. W ostatnich dekadach MSS stały się coraz bardziej skomplikowane i uniwersalne, stanowią element nośny dla wielu urządzeń zarówno podczas wykonywania mostu jak i podczas eksploatacji. Główna struktura systemów MSS może być narażona na efekt zmęczenia, obiążenia zwykle charakteryzują się niską liczbą cykli o znacznej amplitudzie naprężeń. Zmęczeniu można zapobiec poprzez odpowiedni projekt i rozsądny dobór materiałów. Jest to konstrukcja wymagająca ścisłej kontroli jakości i wdrożenia solidnych planów inspekcji i konserwacji.

Słowa kluczowe: mosty, System ruchomych rusztowań - Movable Scaffolding System (MSS), obciążenia zmęczeniowe
\end{abstract}

Editor received the manuscript: 08.07.2016 